\title{
'Anything but an eternal truth': representing left histories Three Representations
}

\author{
Alison C. Forrest, A. M. Givertr, Marcus Klee, Founding Editors, Left History
}

\begin{abstract}
Alison C Forrest
After months of preparation, discussion and publicizing we have a final product at last! As the first issue of left history goes public it is an exciting moment for us. The direction of the journal could take us anywhere (well, almost!). I firmly believe that these things take on a life and a meaning of their own, frequently independent of their genesis. While we won't lose sight of our original intention to create a forum for an interdisciplinary leftist approach to history, it also seems likely that world political events (such as the future of Marxism, the new Clinton administration in the U.S., the rise of fascism and religious fundamentalism) will direct our interests and discussion in future issues of the journal.
\end{abstract}

As a feminist labour historian with an interest in pursuing postmodern/poststructuralist theories I'm committed to creating space for discussion across a number of theoretical positions. I am interested in a critical history, which engages both Marxist theories and postmodern/poststructuralist theories with a feminist politics. In recent years many such attempts to talk across differences have resembled more a slandering and pontificating than a genuine attempt to make common cause with one another. Yet such discussions offer potential rewards for those of us engaged in both writing gender histories and in practicing feminist politics outside the academy. Postmodern/poststructuralist theories allow us to see the gendered and constructed nature of knowledge and language, while laying bare the subjective and gendered nature of so-called objective fields such as science. This approach allows us to begin to unravel some of the ways in which we have come to be gendered beings, with a view to calling into question and changing those invisible structures which continue to bind women to oppressive social relations.

I am interested in exploring the range of power relations acting within social formations that result in oppressions of class, race, gender, sexual orientation or age. The aim here is not to focus on these labels but to move beyond them and explore the similarities and differences arising from such intersections in order that we can better theorize them and move towards a changed social structure. This is not to suggest that such work will be easy. But it is only through the genuine desire to engage in discussion that we will have the potential to harness these different perspectives to a feminist politics. 
And this openness for debate and discussion is all the more important in these times of political uncertainty. With the fall of the wall and the rise of the new right we can no longer afford internecine squabbling, the disconnection of academic debate from a politics of criticism and change, and the belief that women and other 'minority' or 'interest' groups can expect a continued improvement of their status within our community. I believe we should see this time as ripe for political intervention, and a time where the basis of current collective political agreement can be fundamentally questioned and challenged. It is my hope that the new journal, left history, may go some way to opening and facilitating this debate as we look toward an uncertain future, but a future that also offers exciting possibilities for change.

\section{A.M. Givertz}

The philosophy of reality, therefore, proves here again to be pure ideology, the deduction of reality not from itself, but from a concept.

Karl Marx

Postmodemism has interrupted the way we think; it has caused a crisis in theory making, but postmodemism is not something we can escape (even if we wanted to). And like others, we see this crisis as an important opportunity to retheorize and to reconnect. ${ }^{1}$ So our's is a postmodernist strategy; a radical intervention into the "cultural dominant" that will explore and question the conceptual assumptions from which we deduce reality, so that new research and critique might interrupt our ways of knowing and allow space for new ways of thinking.

Much time has passed since Engels noted that, "any demand for equality which goes beyond that of necessity [the proletarian demand for the abolition of classes] which passes into absurdity." At the same time, Engels also realized that the demand for equality is historically contingent. "The idea of equality, both in its bourgeois and its proletarian form, is ... a historical product, the creation of which required definite historical conditions that in turn themselves presuppose a long previous history. It is therefore anything but an eternal truth." 2 Thus, while the abolition of classes (what was necessary then) is still necessary, the demand for equality is much broader, more plural, and must include the demands for racial equality (but not necessarily the end of race), gender equality (but not necessarily the end of gender), sexual equality (but not the end of $\operatorname{sex} .^{3}$

At the heart of this project is the re-expression of the (Enlightenment) construct 'equality.' Notions of equality remain despite postmodernist critique. To reject the possibility of equality is, as Mary Hawkesworth writes, "too cruel a conclusion and too reactionary a political agenda." "Still, we have learned that equality does not have the same meaning for all. Maybe that is why equality is not part of most people's lived experience. 
We have learned, with the help of Engels and postmodernism (of which feminism is an important part), that knowledge is historically contingent. But this does not mean that history is contingent. We need not, for sake of intellectual integrity, deny individual and collective histories of terror and resistance, domination and oppression. We all experience these - for most as disadvantage, for some as privilege. Chronicling these experiences has in large part been the substance of left histories.

This should not be taken for granted.

The appearance of this journal comes at a time when, in Canada a reinvigorated campaign against the production of "left histories" is being waged by two popular mainstream historians, Jack Granatstein and Michael Bliss. Despite being a self-proclaimed social democrat, Granatstein's patience for left histories has dwindled. In a less than charming admonition of the writing of Canadian social history (particularly feminist histories) he made his feelings public: "Really who cares about the history of housemaid's knee in Belleville in the 1890s?"5 Enough said.

The always more sophisticated Bliss encapsulated his critique in an essay entitled "Privatizing the Mind: The Sundering of Canadian History, the Sundering of Canada." In it he charges that "the writing of Canadian history...[has] become specialized, fragmented, and, in both substance and audience appeal, privatized." Bliss thoughtfully includes himself as one of those guilty of "privatizing" history, though for Bliss this has meant, among other things, acting as the corporate (sponsored) historian of Canadian business. Nevertheless, he enjoins his colleagues to "return to national history, to public history, to trying to write the history of Canadians as a people who are united." He also reminds historians that it is their "responsibility to write and talk about Canada... to return to their role as interpreters of the evolution of the public community" for the benefit of Canadians. ${ }^{6}$

What is involved in Bliss's condemnation of localized studies that explore particular experience? Is it directly related to his promotion of national political history, or what he curiously calls "public history" ("which public?" one might ask)? And why was it necessary to construct a historic/mythic role for the historian as national sage? Could this have been an attempt to justify Bliss and Granatstein's newly assumed role as television personalities and experts on all things Canadian? Whether it was Meech Lake, the Referendum, or the CBC Ombudsman's report on the documentary "The Valour and the Horror," this pair was never at a loss for words and never critically self-reflective. To these self-satisfied gurus, who share their wisdom with "helpless" viewers on various tele-boring occasions, one might reply, "really, who cares."

Does this mean that we reject making connections outside of the academy? Certainly not. But, it is necessary that we recognize the limitations and specificities of the academy, especially in North America where making links 
across academic boundaries is rare (we do not share "the French Genius," as Julia Kristeva calls it, for fracturing this/these lines). Unfortunately, in our experience, the only popular meeting ground has been the mass media where academics preside to tell us how/why things are the way they are. Still, we agree with Meagan Morris that it is necessary to resist the universalizing notion of the "institutional and discursive closure" of the academy. ${ }^{7}$ We also believe that in order for academic theories of equality to maintain their presence, as Roberta Hamilton has stated of academic feminism, they must maintain their interconnections with emancipatory social movements." 8 Unfortunately, academics too often have the tendency to dictate what the 'true' emancipatory program is. Ernesto Laclau is a case in point.

In declaring the necessity of massive adjustments to left political discourse in the 1990s, Laclau has described this "moment" as the "most important epochal mutation that the world has experienced since the Second World War." Although we concur with this observation, we do not agree that what Laclau describes as a post-Marxist perspective will alone provide the reformulation of "a political program for the left in the historical circumstances prevailing in the last decade of the twentieth century?"9 The universal self-importance of Laclau's post-Marxism surfaces alongside an equally disturbing acute hostility to marxism (apparent in much of postmodern theorizing) that itself requires some examination.

What is the substance of Laclau's rejection of marxism and more importantly what forms the content of his (and Mouffe's) post-Marxism? It appears that Laclau's self-image turns on a rather defensive assertion of that which he is not, that is, a marxist - is former marxism is constructed as a sophomoric disorder that was rejected in favour of the ultimately more mature theories of post-Marxism; the latter signalling intellectual sophistication. In some sense, then, his anti-marxism can be seen as self-loathing (for that which he was and may not be able to escape entirely from). For discursively, Laclau positions himself, most emphatically, in opposition to that which had so defined him: namely marxism. Therefore, Laclau's political/theoretical subjectivity still remains inextricably linked to marxism. This identity crisis (maybe part of the condition of multiple subjectivities) results in a rather confusing dichotomy of dismissal attachment to the theories of marxism. Thus, for Laclau, marxism is sometimes a thing to be relegated to "the museum of antiquities." Other times it is a thing that "has broken up," but with Laclau "holding on to its best fragments."10 I suppose that makes him its curator keeper. The antagonism of this postMarxism seems, unfortunately, to replicate academic disciplinarianism if not older political sectarianisms. And it is this new theoretical sectarianism that needs to be abandoned in favour of a truly synthetic postmodernism.

To this end, we need only look to feminists for the model -both conceptually and for motivation. Of all the important theoretical approaches, femi- 
nism - signifying a wide range of theoretical formulations and political practices - is the only area of theory production that provides the possibility and the space for sustained auto-critique. Differences that have caused conflicts within feminism have, especially in the last few years, forced many to re-think assumptions that tended to exclude and forced many toward a more inclusive theorizing. ${ }^{11}$ This effort is unusual if not remarkable. It is our hope that we can reproduce a similarly productive if not hospitable climate where difference can be met with dialogue.

We refuse to exclude those remaining marxists - and other "historical left-overs" - from left history (marxist support for this project was indeed profound; those calling themselves post-Marxists were more sceptical). To do so would be to invoke a particular left identity and rather than creating such boundaries, left history shall provide common/collective space for all those who identify with the left. Since knowledge of history is variable, history is always contestable. Its construction is ultimately a political act, driven by theory, though for most, both politics and theory go unacknowledged. In this way left history is a political response and in that sense we have met Michael Bliss's challenge to return to Political history. We suppose, however, that we've chosen the wrong politics.

Yet, left history's politics do not provide some version of the Truth. Our's is not an attempt to reinsert or reinvent objectivity, or to attach it to our historical project. Those coming together in left history do so as sets of differing identities, or collective wills; thus unity is not found in any essential identity that is common to us all. Therefore, the identity of this journal is only presently being articulated and is something that will continue to be constructed and reconstructed. Nonetheless, this project can, admittedly, only be partial. The culmination of this journal, hopefully occurring when it is no longer appropriate as strategy, will demonstrate the claim that "All things that exist deserve to perish." 12 So be it.

Marcus Klee

How long

Do works endure? As long

As they are not completed.

Since as long as they demand effort

They do not decay.

Bertolt Brecht

Bringing a journal into 'existence' is a continuing task. In this sense left history does not exist, or rather, it only exists as a process of renewal; a negotiation between the present and the past in which its purpose and meaning are recast. This process is a personal one requiring the commitment of vast amounts of individual and collective effort and a willingness to resolve the frequent conflicts 
and differences of opinion while simultaneously navigating the politics of labour division. Unity of purpose has never been a distinguishing or unique feature of the left, but then neither has disunity. There are always points of convergence in which collective actions signal a temporary displacement of difference as well as periods of dischord in which individual identities, priorities, and perspectives assert themselves. It therefore seems somewhat ironic that three people who have demonstrated the unity of purpose required to assemble a first issue, and who openly identify with the left and share a commitment to bringing diverse narratives together in a common space are, nonetheless incapable of writing a short introductory statement without sliding into their own personalized and differentiated commentaries.

Certainly an "essential identity" is not invoked by a timely focus upon our similarity rather than our difference. We have worked together from the inception of left history to build a journal with which leftists could identify a journal with which we could identify. I perceive our inability to co-operat "in the last instance" and in such a relatively trivial and ancillary matter as a failure "to make common cause with one another." A year of shared interests and common effort and sacrifice were transformed into individuated positions and theoretical distinctions once our own pens were put to paper. But perhaps our inability to find common ground is not so much a failure as a suitable signifier for our entire project. To make a political and personal statement by speaking in several distinct voices is what left history strives to facilitate. This would not have been denied in the act of writing in a harmonized chorus of voices but the politics of production -which has been a site for negotiated co-operation - were decentered by our differing interest in exploring new perspectives in the writing of social history. Debates around identities and the relations of power which they serve to expose and mystify problematize the assumptions supporting the privileging of certain categories, such as race, class and gender. With this comes a renewed interest in discerning difference, and challenging monoliths.

Given these movements it seems appropriate to momentarily return to the identity of left history and what we intend to convey with this appellation. Much discussion surrounded the title of this latest addition to radical publishing ranging from glib word play to thoughtful criticism of 'left' as a monolithic category and 'history' - in the singular - as a totalizing project. With the name left history, however, we seek not only to designate a particular political possibility which is hardly reducible to just one theoretical strain - but a politics which embraces particularity and difference. We strive to counter what Bliss calls the fragmentation of history into antagonistic interpretive fields and research areas, not by striving for some unifying category or boundary into which all histories will collapse, but by opening a space where seemingly disparate topics and approaches can co-exist to strengthen our under- standing of the past. left history is certainly not alone in its endeavour to expand the categories of historical 
analysis and subjects of study while simultaneously engaging a multitude of methodologies. In a recent article Nancy Hewitt declares that,

If in the midst of debates over political correctness and the conservative backlash, we are going to continue to study the past as a means of illuminating the present, we must avoid being overly cautious.... This means we must test new concepts and theories and new combinations of concepts and theories, from poststructuralism to subaltern studies to new renditions of Marxism and feminism developed by women of color and students of labor.

Hewitt's position is commendable for its capacity to span the debate about categorical primacy and temper the 'crisis' of proliferating identities by exploring new and always shifting theoretical positions. When reading such a convincing and insightful analysis it is easy to forget that the process of uncovering and reconstructing the past is premised upon our own particular politics, which may not be as uniformly flexible. What we choose to illuminate is shaped by personal sensitivities, drawn from our always varied and sometimes tragic lived experiences. To suggest that debate be circumscribed and our own commitment to the importance of a particular identity be suspended in favour of "play[ing] with their interconnections as well as their points of conflict"13 risks establishing a new orthodoxy and distancing us from our political commitments. Rather than insisting that everyone employ such a nuanced approach left history will be a site where the multiple layers of human experience and diverse identities can be explored within a variety of theoretical currents but most importantly these will co-exist within one journal.

It is evident that we, as co-editors, were unable to bridge the gap that separates our different perspectives and priorities, despite a claim to sharing similar politics. Nancy Hewitt urges academics to 'compound' their differences, I would suggest that left history can only 'bind' our differences - bring them together in debate separated by page breaks and white space. And this is not an insignificant achievement especially since in this inauspicious time, traditional funding sources for new publications are growing scarce, libraries are forced to reduce their journal holdings, readers and writers are experiencing varying degrees of financial uncertainty and whether material or discursive. Aware of these constraints, and in defiance of the political current which has brought them to be, we have constructed a new medium for left/critical thinkers from both inside and outside of the university. left history's project of uncovering the numerous marginalized narratives is associated with a commitment to end the isolation of academia and forge constructive links with the arts community and progressive individuals in society. We encourage people with a critical perspective and a political awareness - one which appreciates that standing aside means taking a side - to contribute their written work or engage what is written through the act of reading 


\section{NOTES}

1 See Donna Haraway, "A Manifesto for Cyborg: Science, Technology, and Socialist Feminism in the 1980s" in Linda J. Nicholson ed. Feminism/ Postmodernism (Thinking Gender) (London: Routledge, 1990), 190-233; Judith Butler and Joan Scott eds., Feminists Theorize the Political (London: Routledge 1992).

${ }^{2}$ Frederick Engels, Anti-Dübring: Herr Eugen Diühring's Revolution in Science (Moscow: Progress Publishers. 1947), 132.

${ }^{3}$ Because of my own historical location, I will neglect other significant demands

${ }^{4}$ Mary Hawkesworth, "Knowers, Knowing, Known: Feminist Theory and Claims of Truth" in Micheline R. Malson et al (eds.), Feminist Theory in Practice and Process (Chicago: University of Chicago Press, 1989), 351.

5 Christopher Moore, “The Organized Man,” The Beaver 71 (April-May 1991): 59.

6 Michael Bliss, "Privatizing the Mind: The Sundering of Canadian History, the Sundering of Canada" Journal of Canadian Studies 26 (Winter, 1991-92): 9, 15, 11. 7 Meagan Morris, The Pirate's Fiancée: Feminism Reading Postmodernism (London: Verso, 1988), 10.

8 Roberta Hamilton, "Feminist Theories," Left History 1 (Spring, 1993), 29.

${ }^{9}$ Ernesto Laclau, New Reflections on the Revolution of Our Time (London: Routledge, Chapman \& Hall, 1990), xi-xii.

10 Ibid., 181, 201.

${ }^{11}$ For examples of this dialogue within feminism see Marianne Hirsch and Evelyn Fox Keller (eds.), Conflicts in Feminism (New York: Routledge 1990). 12 This citation is found in Karl Marx, The Eighteenth Brumaire of Louis Napoleon (New York: International, 1963), 21. Marx, however, was quoting Goethe's Faust, tongue-in-cheek of course.

13 Nancy A. Hewitt, "Compounding Differences," Feminist Studies 18, no. 2 (Summer 1992), 323. 